\title{
Length-Weight relationship and condition factor of tilapia species grown in marine and fresh water ponds
}

\author{
Alex Nehemia ${ }^{*}$, Justin D. Maganira and Cyrus Rumisha \\ Department of Biological Sciences, Sokoine University of Agriculture, P.O. Box 3038, \\ Morogoro, Tanzania
}

\begin{abstract}
The aim of this study was to describe the differences in Length-Weight relationship and condition factor of Tilapia zillii and Oreochromis urolepis urolepis reared in full strength sea water (FSSW) and fresh water (FW) ponds. The environmental condition in FSSW and FW ponds were also analyzed to determine their impacts on Length-Weight relationship and condition factor on both species. The regression coefficient "b" exhibit negative allometric growth in FW and positive allometric growth in FSSW for both species. The value of exponent "b" and condition factor $(\mathrm{K})$ for T. zillii in FW and FSSW (in the bracket) were found to be 2.94 (3.3) and 2.07 (0.74) respectively. On the other hand the value of exponent "b" and condition factor $(\mathrm{K})$ for $O$. urolepis urolepis in FW and FSSW (in the bracket) were found to be 2.81 (3.46) and 0.86 (0.53) respectively. Though both species performed well in FW, the study also revelead that farming of these tilapia species in FSSW can be feasible if water quality parameters are properly monitored.
\end{abstract}

Keywords: L-W relationship, Tilapia, Sea water, fresh water, Pangani, Tanzania

\section{INTRODUCTION}

Knowledge of some quantitative aspects such as length-weight relationship is important in studying fish biology. Length-weight relationships can be used to predict weight from length measurements made in the yield assessment (Pauly, 1993). Fish can attain either isometric growth, negative allometric growth or positive allometric growth. Isometric growth is associated with no change of body shape as an organism grows. Negative allometric growth implies the fish becomes more slender as it increase in weight while positive allometric growth implies the fish becomes relatively stouter or deeper-bodied as it increases in length (Riedel et al., 2007).

The condition factor which show the degree of wellbeing of the fish in their habitat is expressed by 'coefficient of condition' also known as length weight factor. This factor is a measure of various ecological and biological factors such as degree of fitness, gonad development and the suitability of the environment with regard to the feeding condition (Mac Gregoer, 1959). When condition factor value is higher it means that the fish has attained a better condition. The condition factor of fish can be affected by a number of factors such as stress, sex, season, availability of feeds, and other water quality parameters (Khallaf et al., 2003).
Tilapias are plastic animals because their growth and maximum obtainable size can be seriously influenced by the physical and biological composition of their environment (Olurin and Aderibigbe, 2006). Because the environment in aquaculture system is complex, water quality parameters such as temperature, $\mathrm{pH}$, concentrations of dissolved oxygen (DO) and ammonia must be monitored. Though other factors are important, oxygen is more essential for growth and survival of a fish because it affects fish respiration as well as nitrite and ammonia toxicity. The minimum DO requirements of tilapia species is 5 $\mathrm{mg} / \mathrm{L}$ and if the concentration of DO decreases, respiration and feeding activities also decrease (Mallya et al., 2007). As a result, the growth rate is reduced and the possibility of disease outbreaks increases. Furthermore, fish are unable to assimilate the food consumed when DO is low (Tom, 1998). The optimal temperature for growth of tilapia ranges from $29^{\circ} \mathrm{C}$ to $31^{\circ} \mathrm{C}$. Growth declines greatly with decreasing temperature and at $20^{\circ} \mathrm{C}$ to $22^{\circ} \mathrm{C}$, growth is about $30 \%$ of optimum (Teichert-Coddington et al., 1997). The lethal minimum temperature for most species of tilapia is $10^{\circ} \mathrm{C}$ or $11^{\circ} \mathrm{C}$ while at $37^{\circ} \mathrm{C}$ to $38^{\circ} \mathrm{C}$ stress and diseases tend to attack most of them (Popma and Lovshin, 1995). 
During phytoplankton busts, both ammonia and Carbondioxide are liberated into the water column. Because freshwater has low buffering effect, Carbondioxide can accumulate in the water, thus lowering the $\mathrm{pH}$ in ponds considerably and reducing the amount of un-ionized ammonia (Tucker et al., 1984). Marine fishponds have large carbonate alkalinity which buffers its effect resulting in relatively higher levels of un-ionized ammonia, which is toxic (Krom et al., 1985). Generally at $\mathrm{pH} 7$ only less than $1 \%$ of the total ammonia is in the toxic un-ionized form, at pH 8 about 5 to $9 \%$, at pH 9 about 30 to $50 \%$, while at $\mathrm{pH} 10$ is about 80 to $90 \%$. The first mortalities from prolonged exposure to toxic ammonia begin at concentration as low as $0.2 \mathrm{mg} / \mathrm{L}$ and this un-ionized form of ammonia begin to depress appetite of tilapia at concentration as low as 0.08mg/L (Popma and Lovshin, 1995).

Although environment of aquaculture is complex, management of the water quality parameters is essential especially if the fish are to be grown in pond culture systems because environmental factors affects the fish body condition, growth performance and yield. In Tanzania few studies have been conducted on length-weight relationship and condition factor of some tilapia species (Mgaya et al., 2005; Rumisha, 2010). The available studies are related to freshwater tilapia species; therefore the aim of the present study is to assess growth patterns and condition factors of Tilapia zillii and Oreochromis urolepis urolepis grown in FSSW and FW ponds.

\section{MATERIALS AND METHOD}

Study site: The Pangani River system (Fig. 1) drains the southern and eastern sides of Africa's highest mountain, Mt. Kilimanjaro as well as Mt. Meru and then flows through the arid Maasai Steppe, the Pare and Usambara mountain ranges before reaching the coastal town of Pangani, forming the estuary with the Indian Ocean. This river has high diversity of tilapia species including $O$. esculentus, $O$. pangani girigan, $O$. pangani korogwe, $O$. pangani pangani, $O$. Jipe, $O$. Variabilis, O. Hunteri, $T$. rendalli, T. Zillii, $T$. Sparrmanii (Eccles, 1992; Dallas et al., 2006 and Bailey, 1996) and O. urolepis urolepis as identified in this study.

The rearing of fingerlings was done at the Institute of Marine Sciences Mariculture Centre (IMS-MC) at Pangani located between latitude $05^{\circ} 10^{\prime}$ and $05^{\circ} 20^{\prime}$ $S$ and longitude $038^{\circ} 50^{\prime}$ and $39^{\circ} 0^{\prime} \mathrm{E}$ Collection and stocking of fingerlings: Fingerling samples were collected from Pangani River using seine nets.
Samples were transported live to IMS-MC at Pangani in plastic containers with open tops that were covered with plastic papers to protect the water from splashing and also from exposure to direct sun. The samples were also transported in the evening to avoid high temperatures. The containers were filled with water to $70 \%$ of its volume and fitted with battery operated aerators.

The samples were sorted and $T$. zillii and $O$. urolepis urolepis were identified according to Eccles (1992) and Pullin (1988). The weight of collected fingerlings ranged between $5.3 \mathrm{~g}$ and $42 \mathrm{~g}(4.77 \mathrm{~cm}$ to $12.32 \mathrm{~cm})$ for Oreochromis urolepis urolepis and $11.9 \mathrm{~g}$ to $15.4 \mathrm{~g}$ ( $7.36 \mathrm{~cm}$ to $10.96 \mathrm{~cm})$ for $T$. zillii.

Ten fingerlings of both $O$. urolepis urolepis and $T$. zillii were stocked in four (4) concrete ponds, $1 \mathrm{~m}^{3}$ each fitted underground to the level of soil surface at IMS-MC. Ten fingerlings were distributed randomly in each pond, and each species was stocked in FW and FSSW. This experiment was conducted for 50 days where by fingerlings were first acclimated to FSSW by raising salinity by 2 per day through addition of the desired amount of seawater to fresh water to 35 salinity. Water quality parameters were measured before and after the addition of the seawater. Both species were then maintained in FSSW for 33days.

Fingerlings were fed manually with commercial feeds (White Rose floating type) twice every day (morning and afternoon) at one end of the pond. Initially the fingerlings were fed at a rate of $5 \%$ of the total body weight (TBW) of the fish and two weeks later $10 \%$ of TBW which was continued to the end to the experiment.

Measurement of weight and length: Fish were mopped on a filter paper before they were weighed to remove excess water from their body in order to ensure accuracy (Anderson and Gutreuter, 1985). Length and weight measurements were taken at the end of the experiment. Weight and length of each individual fish was measured by using a sensitive weighing balance (Digital scale model no: 95364) a measuring board respectively. The length was measured as distance from the snout to the tip of the caudal fin. 


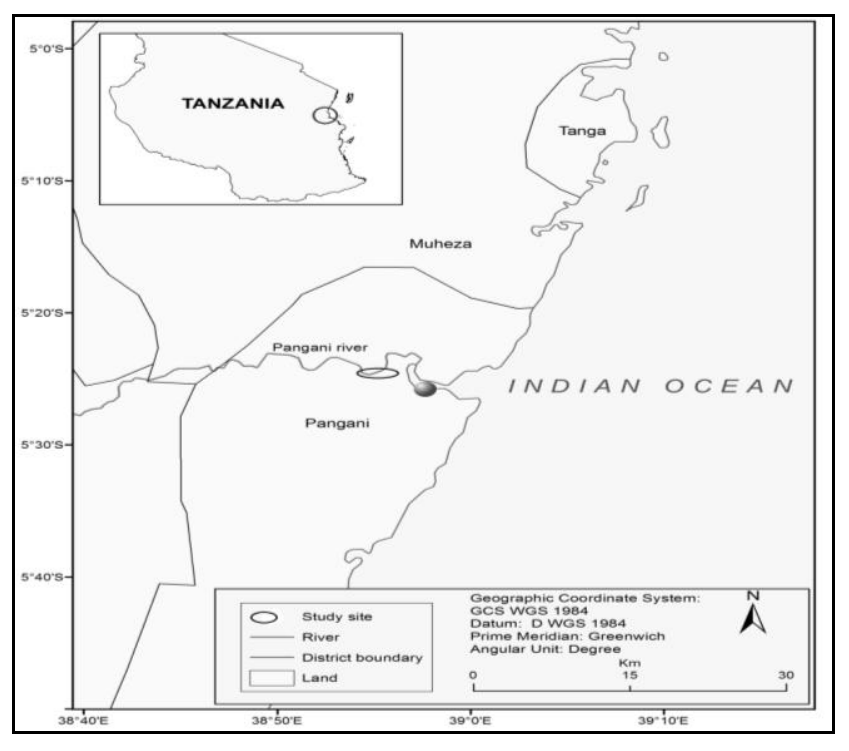

Fig 1: Tilapia fingerling sampling and experimental site at Pangani estuary along the coast of Tanzania

Measurement of environmental parameters: Water quality parameters such as DO, temperature, salinity and $\mathrm{pH}$ were measured throughout the whole period of the experiment in the morning and afternoon. DO was measured with oxygen meter (YIS Environmental model no: $\mathrm{DO} 200)$ and $\mathrm{pH}$ with a $\mathrm{pH}$ meter (HANNA model no: HI 98128). Salinity and water temperature were measured with a refractometer (EXTECH instruments model no: RF20) and a thermometer respectively. Water samples for analysis of ammonium ions were collected once a week in $350 \mathrm{ml}$ plastic containers and stored frozen at $-20{ }^{\circ} \mathrm{C}$ at IMS-MC for the whole period of rearing of fingerlings. The samples were then transported in ice cubes to the IMS in Zanzibar for analysis of ammonia. The concentration of ammonia in the water samples was determined as in UNESCO (1993) with some modifications on the ratios of amount of reagent used to match with the amount of sample needed to be tested.

Data analysis: A student t-test was used to test the differences between ponds in oxygen, temperature, salinity, $\mathrm{pH}$ and ammonia concentration. This was done with the computer program Microsoft Excel, ver., 2007.

The L-W relationship was analyzed by using the equation $\mathrm{W}=\mathrm{aL}^{\mathrm{b}}$ (Pauly, 1983).

Where by $\mathrm{W}=$ weight of fish in gram

\author{
$L=$ Length of fish in $\mathrm{cm}$ \\ $a=$ describe the rate of change of weight \\ with length (intercept) \\ $\mathrm{b}=$ weight at unit length (slope)
}

The equation was log transformed to estimate the parameters ' $a$ ' and ' $b$ '. When $b$ is equal to three (3), isometric pattern of growth occurs but when $b$ is not equal to 3 , allometric pattern of growth occurs, which may be positive if $>3$ or negative if $<3$.

The condition factor which shows the degree of wellbeing of the fish in their habitat was determined by using the equation, $\mathrm{K}=100 \mathrm{~W} / \mathrm{L}^{\mathrm{b}}$ (Gomiero and Braga, 2005).

Where by $\mathrm{K}=$ condition factor

$$
\begin{aligned}
& W=\text { the weight of the fish in gram }(\mathrm{g}) \\
& \mathrm{L}=\text { the total length of the fish in } \\
& \text { centimeters }(\mathrm{cm}) \\
& \mathrm{b}=\text { the value obtained from the length- } \\
& \text { weight equation. }
\end{aligned}
$$

The exponent ' $b$ ' value, that is equal to 3 , was not used to calculate the ' $\mathrm{K}$ ' value. Bolger and Connolly (1989) claim that it is not a real representation of the length-weight relationship for greater majority of fish species, therefore the ' $b$ value used was obtained from the estimated length-weight relationship equation $\left(\mathrm{W}=a L^{b}\right)$ as suggested by Lima-Junior et al. (2002).

\section{RESULTS}

Environmental parameters: The results of environmental parameters are shown in Tables 1. Generally all environmental parameters were within acceptable range for tilapia growth. Figures 2 and 3 compare the concentrations of DO for the two species in fresh water and FSSW respectively. Concentration of DO was high in FW ponds and the differences in DO between FSSW and FW ponds for both species was significant $(P<0.05)$. On average FSSW ponds were observed to have significantly high temperature than FW ponds $(\mathrm{P}<0.05)$. The differences in $\mathrm{pH}$ between FSSW and FW ponds containing $T$. zillii were significant with $\mathrm{FW}$ ponds being lower. The differences in ammonia concentration in all ponds were not significant.

Length - weight relationship: In this study $T$.zillii showed to undergo positive allometric growth at 35 salinity with value of 'b' being 3.3 in FSSW (Fig. 4).

T. zillii showed to undergo negative allometric growth in FW with a 'b' value of 2.94 (Fig. 5). 
Also O. urolepis urolepis showed to undergo positive allometric growth in 35 salinity but negative allometric growth in fresh water. The value of 'b' in FSSW was 3.46 (Fig. 6).

The value of ' $b$ ' for this species in fresh water was found to be 2.81 (Fig.7).
Condition factor: The value of $\mathrm{K}$ for $T$. zilli in both FSSW and FW ponds was high than that of $O$. urolepis urolepis. The maximum value of ' $K$ ' recorded was in FW for both two species with the highest from T. zilii (Table 2).

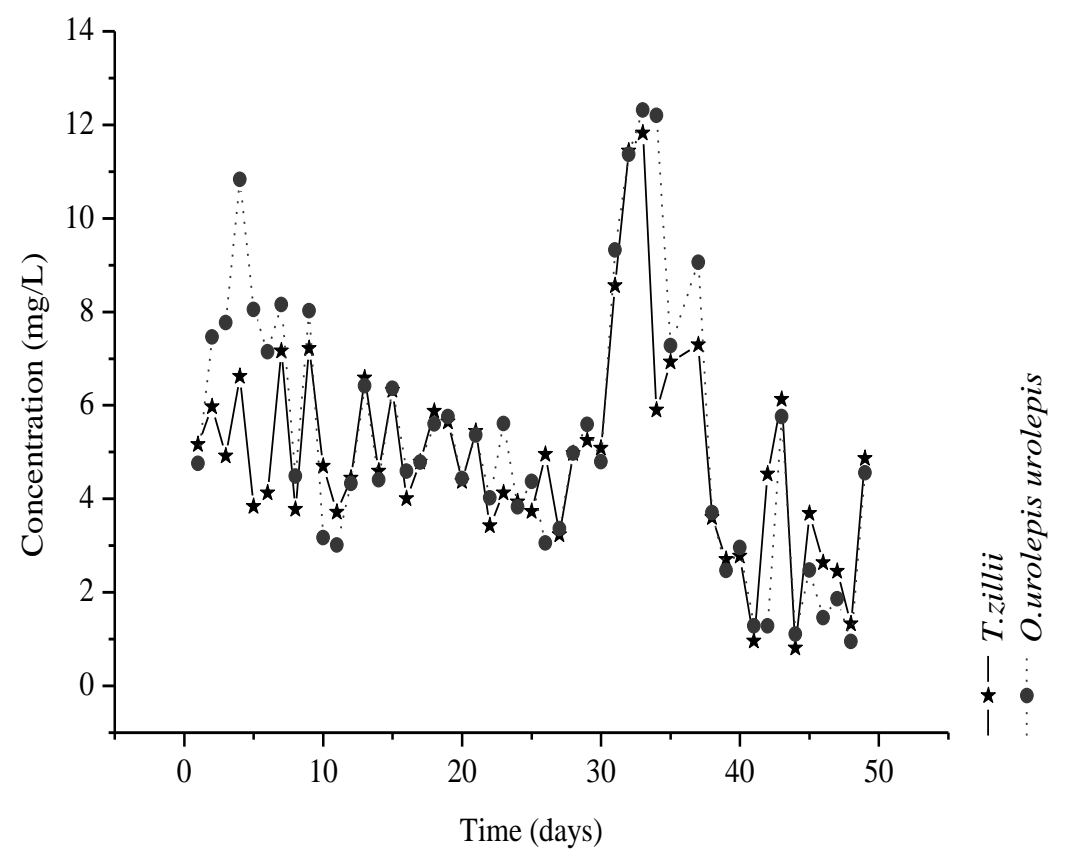

Fig 2: Daily variations of oxygen concentrations in FSSW ponds

Table 1: Average environmental parameters ( \pm s.e)

\begin{tabular}{|c|c|c|c|c|}
\hline & $\begin{array}{c}\text { Water } \\
\text { temperature }\left({ }^{\circ} \mathrm{C}\right) \\
\end{array}$ & $\overline{\mathrm{pH}}$ & $\begin{array}{c}\text { Ammonia } \\
(\mu \mathrm{g} / \mathrm{L})\end{array}$ & $\begin{array}{c}\text { Dissolved Oxygen } \\
(\mathrm{mg} / \mathrm{L})\end{array}$ \\
\hline T. zillii in 35 salinity & $29.41 \pm 0.15$ & $7.74 \pm 0.06$ & $2.78 \pm 0.56$ & $4.92 \pm 0.30$ \\
\hline $\begin{array}{l}\text { T. zillii in fresh water } \\
\text { O. urolepis urolepis in } 35 \\
\text { salinity } \\
\text { O. urolepis urolepis in fresh } \\
\text { water }\end{array}$ & $\begin{array}{l}29.08 \pm 0.15 \\
29.32 \pm 0.14 \\
28.80 \pm 0.14\end{array}$ & $\begin{array}{l}7.66 \pm 0.05 \\
7.72 \pm 0.05 \\
7.67 \pm 0.05\end{array}$ & $\begin{array}{l}5.17 \pm 1.99 \\
1.69 \pm 0.61 \\
4.83 \pm 1.80\end{array}$ & $\begin{array}{l}7.47 \pm 0.33 \\
5.31 \pm 0.41 \\
8.04 \pm 0.39\end{array}$ \\
\hline
\end{tabular}


Agric. Biol. J. N. Am., 2012, 3(3): 117-124

\begin{tabular}{|c|c|c|c|}
\hline & $\mathrm{b}$ & $\mathrm{R}^{2}$ & K \\
\hline T. zillii in 35 salinity & 3.3 & 0.97 & 0.74 \\
\hline T. zilii in fresh water & 2.94 & 0.74 & 2.07 \\
\hline O. urolepis urolepis in 35 salinity & 3.45 & 0.9 & 0.53 \\
\hline O. urolepis urolepis in fresh water & 2.81 & 0.99 & 0.86 \\
\hline
\end{tabular}

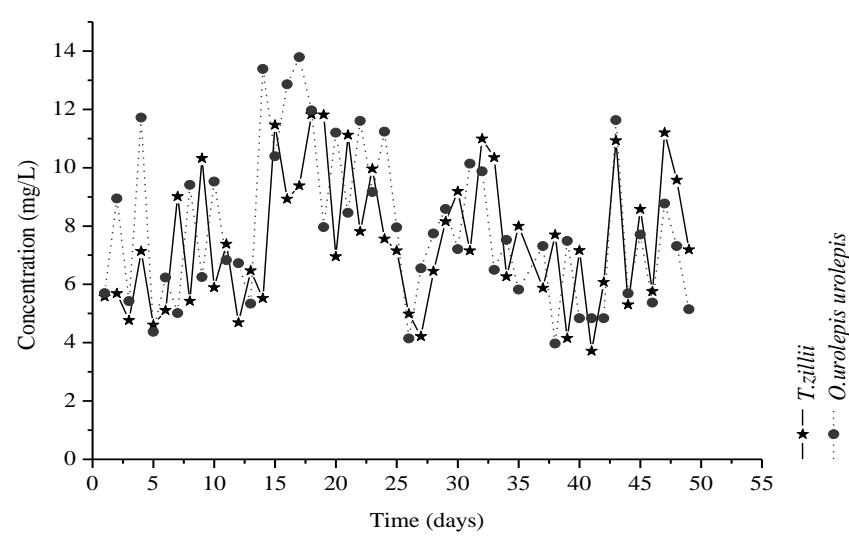

Fig 3: Daily variations of oxygen concentrations in FW ponds

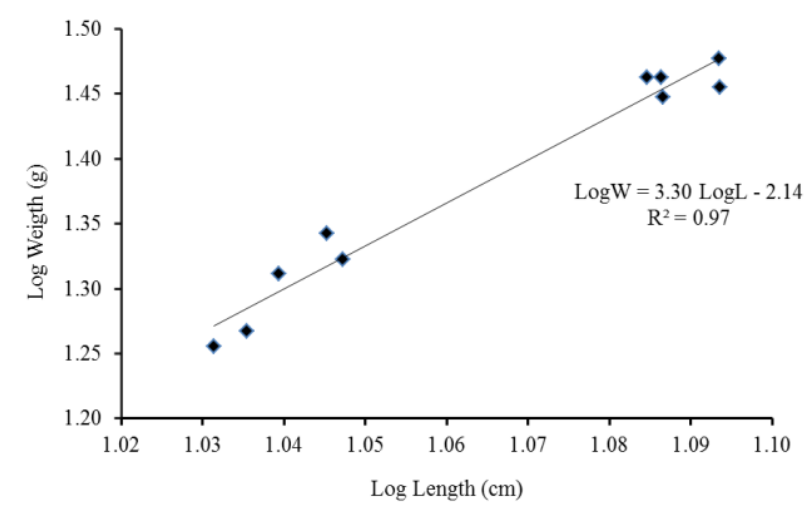

Fig 4: Length - weight relationship of T. zillii in salinity FSSW ponds

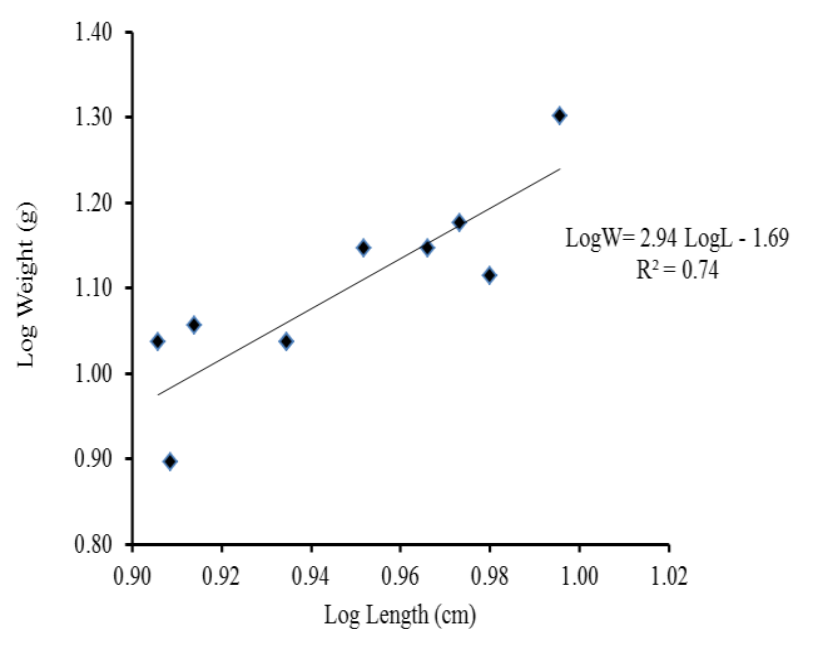

Fig 51: Length - weight relationship of $T$. zillii in FW ponds

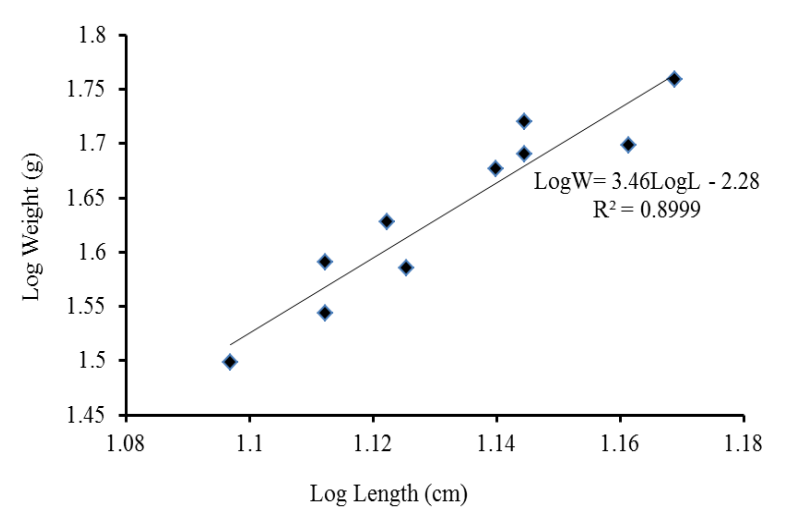

Fig 6: Length - weight relationship of 0 . urolepis urolepis in FSSW ponds 


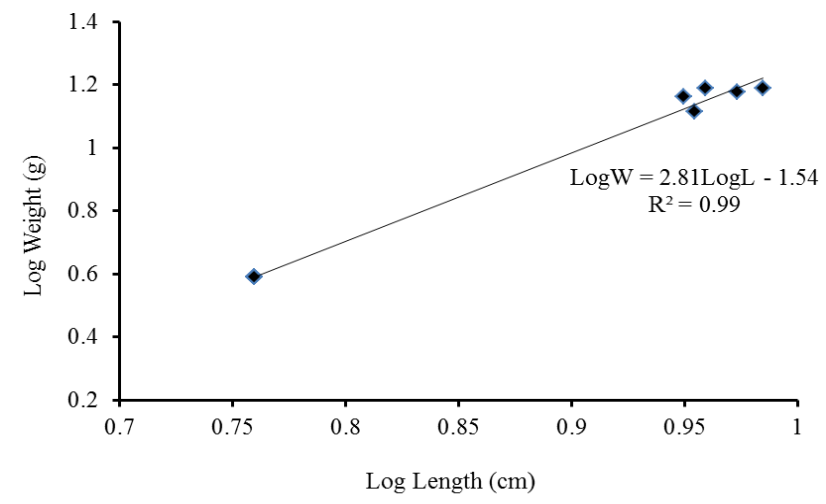

Fig 7: Length - weight relationship of 0 . urolepis urolepis in FW ponds

\section{DISCUSSION}

Length- weight relationship in marine environment : In this study both $T$. zillii and $O$. urolepis urolepis showed positive allometric growth in 35 salinity with 'b' value of 3.3 and 3.45 respectively. Most studies have been done in brackish water but this study was done in FSSW. Negative allometric growth was reported by Mossad (1990) and Ibrahim et al. (2008) for T. zillii in brackish water with a 'b' value of 2.9 and 2.92 respectively. Differences between these findings and the results of this study may be due salinity and other ecological conditions.

Few studies have been done on the hybrids of $O$. urolepis urolepis which is genetically close to $O$. urolepis urolepis. The study by Riedel et al. (2007) recorded 'b' value of 3 for female and 2.9 for male of hybrid crossed between $O$. urolepis urolepis and $O$. mosambicuss in brackish water of the Salton Sea. These results are not the same as those obtained at 35 salinity in this study because of the differing ecological conditions and also being different species though are hybrids of $O$. urolepis urolepis. The reasons for 0 . urolepis urolepis having a higher ' $b$ ' value than $T$. zillii in this study could be due to the fact that these are different species.

Length-weight relationship in fresh water: Both $T$. zillii and $O$. urolepis urolepis showed a negative allometric growth in fresh water (FW) with a ' $b$ ' value of 2.94 and 2.81 respectively. These results are comparable with the findings of other researchers. Negative allometric growth was also reported by Bala et al. (2009) for T. zillii in FW with a 'b' value of 2.91. Also Imam et al. (2010) recorded a 'b' value in T. zillii of 1.53 and 2.5 for wet and dry seasons respectively while Haruna (2006) records were 2.7 to 3.2. The value obtained for $T$. zillii in FW from this study is close to that of Bala et al. (2009) and fall within the range obtained by Haruna (2006) but higher than that obtained by Imam et al. (2010). This difference in results may be due to differences in ecological condition.

The recorded values of ' $b$ ' in fresh water by Mgaya et al. (2005) in floodplain lakes in the lower Rufiji for 0 . urolepis ranged from 2.7-3.0 in Ruwe ponds and from 2.7-2.9 in Uba ponds. These values obtained from Rufiji floodplain are in agreement with the findings of this study. The difference in $b$ value between $T$. zillii and $O$. urolepis urolepis in fresh water might be due to the fact that these are different species.

Condition factor: The condition factors for both $T$. zillii and $O$. urolepis urolepis in FSSW was less than 1 with ' $K$ ' values of 0.74 and 0.53 for $T$. zillii and $O$. urolepis urolepis respectively. The $\mathrm{K}$ values recorded in brackish water for T. zillii by Ibrahim et al. (2008) were 1.94 while Mossad (1990) records ranged from 2.63 to 3.4. The high $\mathrm{K}$ values obtained in these findings compared to the results of this study could be attributed to salinity differences.

The $\mathrm{K}$ value obtained for $T$. zillii in fresh water was greater than one which suggests that the fish was in good condition. The ' $\mathrm{K}$ ' value of $T$. zillii recorded in fresh water by Anene (2005) was 4.3. Imam et al. (2010) records ranged from 2.63-3.4 in dry and wet season while Mahomoud et al. (2011) records ranged between 1.6603 to 2.0190 and 1.6354 to 2.134. The value obtained in this study is within the range obtained by Mahomoud et al. (2011) but comparatively smaller than those obtained by Anene (2005) and Imam et al. (2010) which may be due to different ecological conditions. The $\mathrm{K}$ value of $T$. zillii in freshwater was also greater than that of $O$. urolepis urolepis (Table 2). This could be due to the fact that the average temperature of fresh water ponds containing $O$. urolepis was not within the optimal temperature for growth of tilapia which ranges from $29^{\circ} \mathrm{C}$ to $31^{\circ} \mathrm{C}$ (Table 1). Low average temperature of freshwater ponds containing $O$. urolepis urolepis could be due to shadow effects caused by the nearby trees.

Results of this study showed that both species performed well in freshwater environment that in 
FSSW. This suggests that both species are affected negatively by high level of salinity. Also high concentration of DO measured in fresh water compared to FSSW could be another factor responsible for low values of $\mathrm{K}$ observed in FSSW for both species. Daily variations in DO concentration were observed in both FSSW and FW (Fig. 2 and 3), but the overall concentration of DO was high in FW ponds. High concentration of DO in FW ponds was probably due to high concentration of green algae observed in FW ponds compared to FSWW ponds.

\section{CONCLUSION AND RECOMMENDATION}

Based on the results of Length- weight relationship from this study, both species can be reared in FSSW and FW if environmental parameters are well managed. The study showed that both species exhibited positive and negative allometric growth in FSSW and FW ponds respectively. Also T. zillii showed to have a high condition factor in both environments compared to $O$. urolepis urolepis which mean that $T$. zillii is the best candidate for both FSSW and FW aquaculture compared to O. urolepis urolepis.

In order to enhance mariculture in the coastal areas of Tanzania more researches are still required especially on genetic identification, nutrition and economic feasibility. Information on nutrition and economic feasibility will be useful to local community along the coastal who are involving in small scale aquaculture. The present study focused on $T$. zillii and $O$. urolepis urolepis, it is recommended for future studies to include other species of tilapia in marine environment. The length and weight were measured 33 days after acclimation period, so this study recommends the same study to be carried where by length and weight for determination of Length-weight relationship and condition factors will be measured long period after time of acclimation.

\section{ACKNOWLEDGEMENT}

We wish to express our profound gratitude to the Institute of Marine Sciences of the University of Dar es Salaam for providing laboratory assistance. We are also grateful for Swedish International Development Cooperation Agency for providing financial support.

\section{REFERENCES}

Anene, A (2005). Condition factor of four cichlid species of a man-made lake in Imo State, South-eastern Nigeria.
Turkish Journal of Fisheries and Aquatic Sciences. 5:43-47.

Anderson, R.O., Gutreuter, S.S (1985). Length-weight relationship and associated indices. American fisheries society, pp283-300

Bailey, R. G (1996). Changes in the fish and fisheries ecology of a large man-made lake in Tanzania. Fisheries Management and Ecology. 3:251-260.

Bala, U., Lawal, I., Bolorunduro, P. I., Oniye, S. J., Abdullahi, S. A., Bichi, A. H (2009). Study of ichtyofauna of Daberam reservoir in Katsina State. Bayero Journal of Pure and Applied Sciences. 2:172174.

Bolger, T., P. L. Connolly, P. L (1989). The suitable of suitable indices for the measurement analysis of fish condition. Journal of Fish Biology. 34:171-182.

Dallas, H. F., Kamugisha, S., Lugomela, G., Mbaga, J., Benno, B. L., Kaaya, L. T., Mbago, F. M., Materu, E., Maggida, A., King, J. M., Brown, C. A (2006). River Health Assessment. IUCN Water and Nature Initiative, Pangani Basin Water Office. UNDP, GEF, 185 pp.

Eccles, D. H., 1992. FAO species identification sheets for fishery purposes. Field guide to the freshwater fishes of Tanzania, United Nations Development Programme, Rome, 145 pp.

Gomiero, L. M., Braga, F. M. S (2005). The condition factor of fishes from two river basins in Sao Paulo state, Southeast of Brazil. Acta Scientiarum. 27:73-78.

Haruna, M. A (2006). length-weight relationship of four fish species chichlidae) from magaga lake, kano, Nigeria. Best Journal. 3:109-111.

Ibrahim, S. M., Shalloof, K. A. Sh., Salama, H. M (2008). Effect of Environmental Conditions of Abu-Zabal Lake on Some Biological, Histological and Quality Aspects of Fish,Cairo. Global Veterinaria. 2:257-270.

Imam, T.S., Bala, U., Balarabe, M.L., Oyeyi, T.I (2010). Length-weight relationship and condition factor of four fish species from Wasai Reservoir in Kano, Nigeria. African Studies. 6:125-130.

Khallaf, E., Galal, M., Athuman, M (2003). The biology of Oreochromis niloticus in a polluted canal. Ecotoxicology. 12:405-416

Krom, M. D., Porter, C., Gordin, H (1985). Causes of fish mortality in semi intensively operated seaweed ponds in Eilat, Israel. Aquaculture. 49:159-177.

Lima-Junior, S. E., Cardone I. B., Goite, R (2002). Determination of a method for calculation of Allometric Condition Factor of fish. Acta scientiarum. 24:397- 400.

Mac Gregoer, J. S (1959). Relation between fish condition and population size in the sardine (Sardinops 
cacrulea). U.S. Fishery Wild Service, Fish Bulletin. 60:215-230.

Mahomoud, W.F., Amin, A.M.M., Elboray, K.F., Ramadhan, A.M., El-Halfawy M.M.K.O (2011). Reproductive biology and some observation on the age, growth, and management of Tilapia zilli ( Gerv , 1848 ) from Lake Timsah, Egypt. International Journal. 3:15-25.

Mallya, Y. J (2007). The effects of dissolved oxygen on fish growth in aquaculture, Kingolwira National Fish Farming Centre, Fisheries Division Ministry of Natural Resources and Tourism Tanzania. UNU-Fisheries Training Programme, $30 \mathrm{pp}$.

Mgaya, Y. D., Nkwengulila, G. Kivaisi A., Lymo T., Sobo, F., Lamtane, A (2005). Fingerponds, fourth annual report Contract Number: ICA4-CT-2001-10037, University of Dar es Salaam, Tanzania Department of Zoology and Wildlife conservation (UDSM), 166 pp.

Mosaad, M. N. M., 1990. Biological studies on five fish species from Lake Qarun, Egypt Length-weight releationship and condition factor. Journal of Zoological Society. 21: 331-344.

Olurin, K.B., Aderibigbe, O.A (2006). Length-Weight Relationship and Condition Factor of Pond Reared Juvenile Oreochromis niloticus. Journal of Zoology $1: 82-85$

Pauly, D (1983). Some simple methods for the assessment of tropical fish stocks. FAO Fisheries Technical paper, (234), FAO, Rome, Italy, 52 pp.

Pauly,D (1993). Linear regressions in fisheries research. Journal of the Fisheries Research Board of Canada, 30:409-434.
Popma, J. T., Lovshin L.L (1995). Worldwide prospects for commercial production of Tilapia, Alabama 36849, 42 pp.

Pullin, R.S.V (1988). Tilapia genetic resources for aquaculture. ICLARM Conference Proceedings 16, International Center for Living Aquatic Resources Management, Manila, Philippines, 108 pp.

Riedel, R., Caskey, L.M., Hurlbert, S.H (2007). Lengthweight relations and growth rates of dominant fishes of the Salton Sea: implications for predation by fish-eating birds. Lake and Reservoir Management. 23:528-535.

Rumisha, C.C (2010). Nile tilapia of Lake Victoria and fish ponds in its basin. VDM Verlag Dr. Müller GmbH \& Co. KG, Saarbrücken, Germany.

Teichert-Coddington, Popma, D. R., T. J., Lovshin L. L (1997). Attributes of tropical pond-cultured fish. In: $\mathrm{H}$. S. Egna and C. E. Boyd (eds.), Dynamics of Pond Aquaculture. CRC Press, Boca Raton, Florida, USA, pp 183-198.

Tom, L (1998). Nutritional and Feeding of Fish. Kluwer Academic Publishers. Second edition Boston, USA, $267 \mathrm{pp}$.

Tucker, C. S., Lloyd, S. W., Busch, R. L(1984). Relationship between phytoplankton periodicity and the concentrations of total and un-ionized ammonia in channel catfish ponds. Hydrobiologia. 111:75-79.

UNESCO (1993). Manuals and Guides: Nutrient analysis in tropical marine waters. Practical guidance and safety notes for the performance of dissolved micronutrient analysis in sea water with particular reference to tropical waters, $24 \mathrm{pp}$. 